\title{
How can you survive a cardiac operation after cardiac operation? (analysis of pre- and postoperative data of redone cardiac operations)
}

\author{
M Vaszily", B Matlakovics, R Paulinyi \\ From 23rd World Congress of the World Society of Cardio-Thoracic Surgeons \\ Split, Croatia. 12-15 September 2013
}

\section{Backgrund}

The reoperations in cardiac surgery are technically more difficult, and the mortality and morbidity increased. It is huge importance of operative techniques, preoperative planning and the skills of the surgical team in those cases. We like to detect the different pre- and intraoperative reasons of the elevated morbidity and mortality, and the opportunities, how we could to reduce them.

\section{Methods}

It was 79 REDO cardiac operations in our department during the last 2 years. The previous operations were: mitral valve $(n=33)$, aortic valve (AVR) $(n=15)$, CABG $(n=22), A V R$ and CABG operations $(n=4)$. We recorded the ejection fraction (EF), right ventricular pressure (RVP), intra-operative and postoperative complications, mortality, and postoperative bleeding.

\section{Results}

The most common reason of major bleeding injuries (MBI) was the damage of right ventricle $(25 \%$ of all MBI). In contrast to the literary data, in our cases the MBI were not increased the mortality, and the mean intensive care unit (ICU) time. The early ventricular fibrillation $(13,6 \%)$, the MBI $(36,4 \%)$ intra-arterial balloon pump application $(13,6 \%)$ and mortality $(18,2 \%)$ was higher after previous CABG operations. The incidence of non-fatal complications, MBI and the mortality were significant higher in those patients who had lower EF before, or/and higher RVP.

\footnotetext{
* Correspondence: vaszilym@hm.gov.hu

* Correspondence: vaszilym@hm.gov.hu
Hungarian Defense Forces; Health Center, Department of Cardio-Thoracic and Vascular Surgery, Budapest, Hungary
}

\section{Conclusion}

The lower EF and higher RVP increases the mortality and elongated the mean ICU time. Due to this objects the REDO operation is indicated in the first time of the detection of necessity. The high RVP increase the possibility of MBI. In those cases the possible serious complications can be prevented by peripheral canulation, and the use of external defibrillator paddles. With proper preoperative planning and meticulous surgical techniques, the mortality and the serious postoperative complications can be reduced.

Published: 11 September 2013

doi:10.1186/1749-8090-8-S1-0130

Cite this article as: Vaszily et al:. How can you survive a cardiac

operation after cardiac operation? (analysis of pre- and postoperative data of redone cardiac operations). Journal of Cardiothoracic Surgery 2013 8(Suppl 1):0130.

Submit your next manuscript to BioMed Central and take full advantage of:

- Convenient online submission

- Thorough peer review

- No space constraints or color figure charges

- Immediate publication on acceptance

- Inclusion in PubMed, CAS, Scopus and Google Scholar

- Research which is freely available for redistribution

Submit your manuscript at www.biomedcentral.com/submit
Biomed Central

(c) 2013 Vaszily et al; licensee BioMed Central Ltd. This is an Open Access article distributed under the terms of the Creative Commons 